\title{
UJI AKTIVITAS ANTIOKSIDAN EKSTRAK ETANOL KULIT BUAH RAMBUTAN (Nephelium lappaceum, L.) DENGAN METODE LINOLEAT-TIOSIANAT
}

\author{
Suparmi ${ }^{1 *}$, Hady Anshory ${ }^{2}$, Niche Dirmawati ${ }^{3}$ \\ 1,2,3 Program Studi Farmasi Fakultas Matematika dan IImu Pengetahuan Alam \\ Universitas Islam Indonesia
}

*e-mail: -

\begin{abstract}
ABSTRAK
Rambutan adalah buah yang banyak dikonsumsi masyarakat dan digunakan untuk pengobatan. Kulit buah rambutan diketahui mengandung senyawa aktif flavonoid. Beberapa flavonoid dari tanaman diketahui mempunyai aktivitas antioksidan. Berdasarkan hal tersebut maka dilakukan penelitian aktivitas antioksidan ekstrak etanol kulit buah rambutan (Nephelium lappaceum, L.) dengan menggunakan metode linoleat-tiosianat ditinjau dari daya penghambatan pembentukan radikal bebas asam linoleat. Ekstrak etanol kulit buah rambutan diperoleh dari metode penyarian berkesinambungan dengan menggunakan alat soxhlet. Seri konsentrasi ekstrak dan vitamin $\mathrm{E}(\alpha$ tokoferol) yang digunakan adalah $10 \mu \mathrm{g} / \mathrm{ml}$, $20 \mu \mathrm{g} / \mathrm{ml}, 40 \mu \mathrm{g} / \mathrm{ml}$, $80 \mu \mathrm{g} / \mathrm{ml}$, dan 160 $\mu \mathrm{g} / \mathrm{ml}$. Kemampuan menghambat pembentukan radikal bebas asam linoleat dihitung berdasar nilai absorbansi yang diamati pada panjang gelombang $499 \mathrm{~nm}$. Dari data ini diketahui bahwa ekstrak etanol kulit buah rambutan mempunyai kemampuan yang sama dengan vitamin $\mathrm{E}$ dalam menghambat pembentukan radikal bebas asam linoleat.
\end{abstract}

Kata kunci: antioksidan, asam linoleat, ekstrak etanol, rambutan

\section{ABSTRACT}

People like to eat rambutan and use it as medicine as well. Pericarp of rambutan known contain flavonoid as active compound. Pericarp of rambutan is known to contain flavonoid as an active compound. Based on that fact, the antioxidant activity of ethanol extract of rambutan pericarp (Nephelium lappaceum, L.) was studied using linoleic-thiocyanate method confirming from its free radical linoleic acid formation blocking capacity. Ethanol extract from pericarp of rambutan was obtained from continous extraction method using soxhlet extractor. On this research, series of the ethanol extract of rambutan pericarp and vitamin $\mathrm{E}$ ( $\alpha$ tocopherol) were $10 \mu \mathrm{g} / \mathrm{ml}, 20$ $\mu \mathrm{g} / \mathrm{ml}, 40 \mu \mathrm{g} / \mathrm{ml}, 80 \mu \mathrm{g} / \mathrm{ml}$, and $160 \mu \mathrm{g} / \mathrm{ml}$. Free radical linoleic acid formation blocking capacity was counted based on absorbance which was measured at $\lambda 499 \mathrm{~nm}$. Data showed the ethanol extract of rambutan pericarp have the same ability with vitamin $\mathrm{E}$ in blocking free radical linoleic acid.

Keywords: antioxidant, ethanol extract, linoleic acid, rambutan

\section{PENDAHULUAN}

Menjadi tua adalah suatu proses alami yang tak dapat dihindarkan dan berlangsung secara terus-menerus yang ditandai pada perubahan sel-sel tubuh. Memasuki usia 40 tahun, seseorang akan mengalami proses penuaan secara nyata. Kulit mulai tampak berkeriput dan kering sebab produksi kelenjar keringat kulit mulai menurun. Proses ini diikuti pigmentasi kulit makin meningkat dan rambut mulai beruban. Gejala negatif lainnya adalah stres, penyakit jantung, katarak dan perubahan kejiwaan yang makin merosot. Penyakit jantung akan semakin cepat bersemayam dalam tubuh jika 
seseorang kerap mengalami kondisi stres yang akan merangsang peningkatan kolesterol darah khususnya LDL sehingga akan lebih berisiko terhadap penyakit jantung koroner (Sibuea, 2003).

Radikal bebas adalah molekulmolekul reaktif dan dapat merusak, yang mempunyai elektron tidak berpasangan. Bilamana menerima hidrogen, radikal bebas menjadi tidak reaktif. Pembentukan radikal bebas terjadi dalam tubuh pada proses metabolisme aerobik normal pada waktu oksigen secara bertahap direduksi menjadi air. Radikal bebas yang dapat merusak tersebut juga diperoleh tubuh dari polusi, ozon, dan asap rokok (Almatseir, 2001). Jika radikal bebas sudah terbentuk dalam tubuh maka akan terjadi reaksi berantai dan menghasilkan radikal bebas baru yang akhirnya jumlahnya terus bertambah. Selanjutnya akan menyerang sel-sel tubuh kita sehingga terjadilah kerusakan jaringan yang akan mempercepat proses penuaan. Salah satu teori penuaan yang cukup terkenal mengatakan bahwa akumulasi kerusakan jaringan oleh radikal bebas bertanggung jawab atas proses penuaan satu spesies (Sibuea, 2003).

Antioksidan merupakan senyawa yang dapat menghambat spesies oksigen reaktif/ spesies nitrogen reaktif (ROS/NOS) dan juga radikal bebas sehingga antioksidan dapat mencegah penyakit-penyakit yang dihubungkan dengan radikal bebas seperti karsinogenesis, kardiovaskuler, dan penuaan (Halliwell and Gutteridge, 2000). Zat antioksidan bukanlah substansi kimia aneh yang dihasilkan melalui proses yang menghabiskan milliaran rupiah, melainkan adalah zat-zat yang umum kita kenal seperti vitamin $E$ dan C. Substansi-substansi ini sudah terbukti mampu mencegah oksidasi yang berlebihan dalam tubuh kita. Antioksidan sebenarnya didefinisikan sebagai inhibitor yang bekerja menghambat oksidasi dengan cara bereaksi dengan radikal bebas reaktif membentuk radikal bebas tak reaktif yang relatif stabil. Tetapi mengenai radikal bebas yang berkaitan dengan penyakit, akan lebih sesuai jika antioksidan didefinisikan sebagai senyawasenyawa yang melindungi sel dari efek berbahaya radikal bebas oksigen reaktif (Sofia, 2003).

Sesuai dengan kemajuan dan perkembangan teknologi, tumbuhan alam diketahui dapat berkhasiat sebagai obat, tetapi harus juga diketahui zat aktif di dalam tumbuhan tersebut. Salah satu bahan aktif yang menjadi perhatian banyak peneliti dalam bidang obat-obatan adalah flavonoid. $\mathrm{Hal}$ ini sangat relevan karena flavonoid tersebar merata atau terdapat pada seluruh tumbuhan mulai dari fungi sampai angiospermae (Robinson, 1995).

Senyawa-senyawa polifenol seperti flavonoid yang terdapat pada tanaman mampu menghambat reaksi oksidasi melalui mekanisme penangkapan radikal (radical scavenging) dengan cara menyumbangkan satu elektron pada elektron yang tidak berpasangan dalam radikal bebas sehingga banyaknya radikal bebas menjadi berkurang (Pokorni et al., 2001). Secara in vitro, flavonoid merupakan inhibitor yang kuat terhadap peroksidasi lipid, sebagai penangkap spesies oksigen atau nitrogen yang reaktif, dan juga mampu menghambat aktivitas enzim lipooksigenase dan sikloogsigenase (Halliwell and Gutterigde, 2000). 
Rambutan adalah salah satu buah yang sering digunakan oleh masyarakat untuk pengobatan. Kulit buah rambutan mengandung flavonoid (Anshory et al., 2006). Beberapa flavonoid dari tanaman diketahui mempunyai efek anti radikal bebas atau antioksidan (Rohman dan Riyanto, 2005, Anshory et al., 2006) telah melakukan penelitian aktivitas antioksidan ekstrak etanol kulit buah rambutan dengan metode DPPH, dan hasil dari penelitiannya menunjukkan bahwa ekstrak etanol kulit buah rambutan mempunyai aktivitas antioksidan yang baik. Meskipun suatu senyawa uji menunjukkan daya antioksidan yang tinggi dengan salah satu metode, tidak selalu akan memberikan hasil yang sama baiknya dengan menggunakan metode lainnya sehingga disarankan untuk mengukur daya antioksidan dengan berbagai macam metode (Takaya et al., 2003). Berdasarkan hal tersebut maka sangat menarik dilakukan pengkajian kemampuan antioksidan ekstrak kulit buah rambutan (Nephelium lappaceum, L) secara in-vitro ditinjau dari daya penghambatan pembentukan senyawa radikal bebas dengan metode linoleattiosianat dengan pembanding vitamin $\mathrm{E}(\alpha$ tokoferol).

\section{METODE PENELITIAN}

Bahan yang digunakan dalam penelitian ini adalah kulit buah rambutan (Nephelium lappaceum, L.) yang berwarna merah dan sudah masak yang diperoleh dari daerah Gentan, Sleman, Yogjakarta, asam linoleat, ammonium tiosianat, etanol pa (Merck), buffer pospat $\mathrm{pH} 7$, fero klorida, aquadestilata, asam klorida, vitamin $\mathrm{E}$ ( $a$ tokoferol) (Merck), plat $\mathrm{KLT} \mathrm{GF}_{254}$, serbuk magnesium, pereaksi semprot $\mathrm{AlCl}_{3}$, etil asetat, asam asetat, asam formiat, rutin, dan petroleum eter.

Alat-alat yang digunakan adalah mesin penyerbuk (Grinder) (Honda), alat-alat gelas (Pyrex), alat soxhlet (Pyrex), timbangan analitik (Mettler Toledo tipe PL 303, Dragon 205), vacum rotary evaporator (Heidolp tipe Heizbad WB), desikator, gunting, bejana kromatografi, pipa kapiler, lampu UV, cuvet, dan spektrofotometer (Shimadzu).

\section{Pembuatan ekstrak etanol kulit buah rambutan}

Determinasi tanaman dilakukan di Laboratorium Biologi Farmasi FMIPA UII dengan berdasarkan buku Flora of Java. Bagian dari tanaman rambutan yang digunakan untuk determinasi adalah ranting, daun, dan buah yang diamati sesuai dengan petunjuk buku Flora of Java (Backer and Van de Brink, 1965).

Kulit buah rambutan hasil sortasi dikeringkan di lemari pengering pada suhu sekitar $40-50^{\circ} \mathrm{C}$ selama 6 hari lalu diserbuk menggunakan mesin penyerbuk kemudian ditempatkan dalam plastik bersih. Serbuk diekstraksi menggunakan petroleum eter kemudian setelah itu dengan etanol menggunakan alat soxhlet. Untuk setiap $30 \mathrm{~g}$ serbuk digunakan $150 \mathrm{ml}$ etanol. Setelah cairan penyari jernih, proses ekstraksi dihentikan, selanjutnya ekstrak etanol diuapkan menggunakan vacum rotary evaporator hingga diperoleh ekstrak kental. Ekstrak kental kemudian disimpan di desikator.

Identifikasi kandungan flavonoid ekstrak etanol kulit buah rambutan 
Pemeriksaan dengan Kromatografi Lapis Tipis (KLT)

Ekstrak dilarutkan dalam etanol ditotolkan sekitar 5 totolan pada plat kemudian dimasukkan dalam bejana yang telah jenuh berisi fase gerak etil asetat:asam formiat:asam aetat:air (100:11:11:27), kemudian fase gerak dibiarkan merambat sampai batas yang ditentukan. Setelah itu lempeng disemprot dengan $\mathrm{AlCl}_{3}$ dan diamati di bawah lampu UV 254 nm, 365 nm, dan visibel. Kemudian hitung nilai $R_{f}$ dan bandingkan dengan kromatogram zat pembanding.

Uji daya antioksidan ekstrak etanol kulit buah rambutan dengan metode linoleattiosianat dengan pembanding vitamin $\mathrm{E}$

Ekstrak etanol ditambah $130 \mu \mathrm{l}$ asam linoleat, $10 \mathrm{ml}$ etanol, dan $10 \mathrm{ml}$ buffer fosfat $\mathrm{pH} 7$ kemudian ditambah aquadest sampai volume $25,0 \mathrm{ml}$ hingga diperoleh konsentrasi $10 \mu \mathrm{g} / \mathrm{ml}, 20 \mu \mathrm{g} / \mathrm{ml}, 40 \mu \mathrm{g} / \mathrm{ml}, 80$ $\mu \mathrm{g} / \mathrm{ml}$, dan $160 \mu \mathrm{g} / \mathrm{ml}$. Larutan ini kemudian diinkubasi pada suhu $40^{\circ} \mathrm{C}$ selama 7 hari, dan setiap 12 jam sekali diukur kandungan peroksidanya dengan cara: diambil $200 \mu \mathrm{l}$ larutan diatas, lalu ditambah 9,4 ml etanol; $200 \mu$ larutan amonium tiosianat 10\%; dan $200 \mu$ fero klorida $(20 \mathrm{mM}$ dalam 3,5\% $\mathrm{HCl}$ ), lalu divortek selama 3 menit dan diukur absorbansinya pada panjang gelombang maksimum. Dilakukan juga pengukuran absorbansi kontrol (asam linoleat) seperti semua proses diatas tapi tanpa penambahan ekstrak etanol kulit buah rambutan. Hasil daya antioksidan ekstrak etanol kulit buah rambutan dibandingkan dengan pembanding vitamin $E$ yang sudah diketahui sebagai antioksidan.

Aktivitas antioksidan ditentukan dengan metode linoleat-tiosianat. Data absorbansi yang diperoleh selanjutnya dihitung daya penghambatannya (\%) terhadap oksidasi kontrol (asam linoleat) dengan rumus:

Daya penghambatan $(\%)=($ absorbansi kontrol - absorbansi sampel $) \times 100 \%$

Absorbansi kontrol

Data absorbansi dianalisis dengan metode General Linear Model (GLM). Kemudian nilai absorbansi antara ekstrak etanol kulit buah rambutan dan vitamin $\mathrm{E}$ ( $\alpha$ tokoferol) dibandingkan secara statistik menggunakan Independent Sample T-Test.

\section{HASIL DAN PEMBAHASAN}

\section{Hasil identifikasi kandungan flavonoid ekstrak etanol kulit buah rambutan}

Identifikasi lanjutan flavonoid dengan KLT, menggunakan fase diam silika gel $\mathrm{GF}_{254}$ dan fase gerak etil asetat:asam
formiat:asam asetat:air dengan perbandingan 100:11:11:27 didapat profil kromatogram ekstrak (Gambar 1) yaitu mempunyai 1 bercak dengan warna bercak kuning kecoklatan pada lampu visibel, pada pembanding rutin bercak berwarna kuning. Warna kuning kecoklatan pada lampu visibel tersebut menunjukkan adanya flavonoid dalam ekstrak. Kemudian setelah disemprot dengan pereaksi $\mathrm{AlCl}_{3}$ dan diamati pada lampu visibel dan sinar UV 254 warna bercak kuning tersebut semakin tebal sehingga menunjukkan adanya flavonoid. Pada sinar UV 365 warna bercak dari ekstrak terjadi 
peredaman dan pada pembanding rutin bercak berwarna biru tua. Harga $R_{f}$ ekstrak adalah 0,94 sedangkan $R_{f}$ pembanding rutin adalah 0,75. Dari harga $R_{f}$ tersebut menunjukkan bahwa ekstrak etanol kulit buah rambutan mengandung flavonoid.

Tabel 1. Hasil pembacaan warna bercak KLT ekstrak etanol kulit buah rambutan dan pembanding (rutin) setelah disemprot dengan $\mathrm{AlCl}_{3}$

\begin{tabular}{|c|c|c|c|c|c|c|}
\hline \multirow{2}{*}{ Sampel } & \multicolumn{2}{|r|}{ Visibel } & \multicolumn{2}{|r|}{ UV 254} & \multicolumn{2}{|r|}{ UV 365} \\
\hline & $\mathrm{hR}_{\mathrm{f}}$ & Warna & $\mathrm{hR}_{\mathrm{f}}$ & Warna & $\mathrm{hR}_{\mathrm{f}}$ & Warna \\
\hline Ekstrak & 94 & Kuning kecoklatan & 94 & Kuning kecoklatan & 94 & Peredaman \\
\hline Pembanding & 75 & Kuning & 75 & Kuning & 75 & Biru tua \\
\hline
\end{tabular}

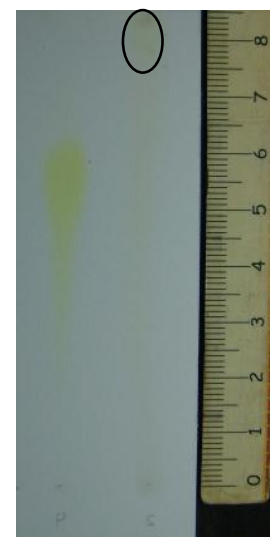

P S Visibel

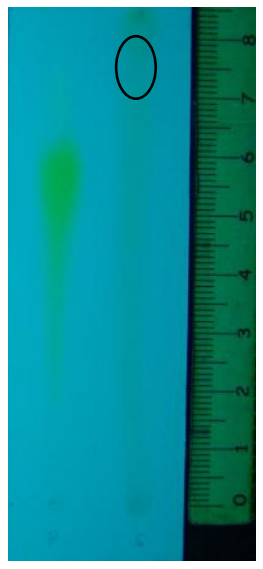

P S UV 254

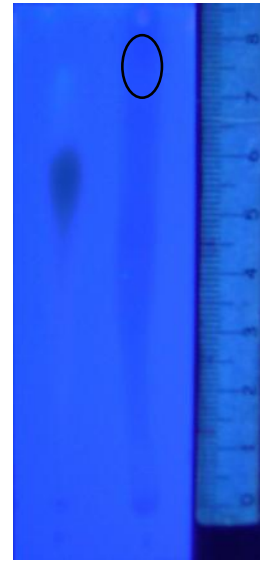

$P \quad S$ UV 365

Gambar 1. Profil kromatogram flavonoid ekstrak dan pembanding (Rutin).

Keterangan: $\mathrm{P}=$ Pembanding (Rutin); $\mathrm{S}=$ Ekstrak; Fase diam = Silika gel GF 254 ; Fase gerak = Etil asetat:Asam Formiat:Asam asetat:Air (100:11:11:27)

\section{Hasil uji aktivitas antioksidan ekstrak etanol kulit buah rambutan}

Uji aktivitas antioksidan ekstrak etanol kulit buah rambutan menggunakan metode linoleat-tiosianat dengan pembanding vitamin $\mathrm{E}$ yang telah diketahui mempunyai aktivitas sebagai antioksidan. Sebelumnya telah dilakukan uji aktivitas antioksidan ekstrak etanol kulit buah rambutan dengan metode DPPH yang menyatakan bahwa ekstrak tersebut mempunyai aktivitas sebagai antioksidan yang baik. Namun demikian, meskipun suatu senyawa uji menunjukkan daya antioksidan yang tinggi dengan salah satu metode, tidak selalu akan memberikan hasil yang sama baiknya dengan menggunakan metode yang lain. Disamping itu Metode linoleat-tiosianat lebih memberikan gambaran proses penghambatan radikal bebas secara bertahap, karena diuji dan diamati setiap hari selama 7 hari berturut-turut.

Pengukuran aktivitas antioksidan dengan metode linoleat-tiosianat dilakukan dengan cara melihat jumlah peroksida yang terbentuk selama inkubasi sampel yang diukur secara spektrofotometri, yaitu mengukur absorbansi pada panjang gelombang maksimum. Tingginya nilai absorbansi mengindikasikan tingginya konsentrasi peroksida yang terbentuk (Yildirim et al., 2001). 
Larutan uji yang digunakan diperoleh dengan mencampur ekstrak etanol kulit buah rambutan maupun vitamin $E$ dengan asam linoleat, buffer fosfat, etanol, dan aquadest hingga diperoleh seri konsentrasi $10 \mu \mathrm{g} / \mathrm{ml}, 20 \mu \mathrm{g} / \mathrm{ml}, 40 \mu \mathrm{g} / \mathrm{ml}, 80$ $\mu \mathrm{g} / \mathrm{ml}$, dan $160 \mu \mathrm{g} / \mathrm{ml}$ kemudian diinkubasi pada suhu $40^{\circ} \mathrm{C}$ selama 7 hari. Sedangkan untuk kontrol, diperoleh dari campuran asam linoleat, buffer fosfat, etanol, dan aquadest. Setiap 12 jam sekali larutan uji tersebut direaksikan dengan etanol, ammonium tiosianat, dan ferro klorida dan terbentuk warna merah. Kemudian larutan tersebut diukur absorbansinya pada panjang gelombang maksimum $499 \mathrm{~nm}$. Absorbansi menunjukkan jumlah radikal bebas asam linoleat yang tidak dinetralkan oleh ekstrak etanol kulit buah rambutan maupun vitamin E. Radikal bebas yang tidak dinetralkan oleh ekstrak etanol kulit buah rambutan maupun vitamin $\mathrm{E}$ tersebut akan mengoksidasi ion ferro (dari ferro klorida) menjadi ferri. Kemudian dengan adanya ammonium tiosianat terbentuk ferri-tiosianat yang berwarna merah. Dalam hal ini penghambatan terbentuknya radikal bebas ditandai dengan berkurangnya intensitas warna merah karena kompleks ferri-tiosianat yang terbentuk semakin berkurang sehingga absorbansi yang diperoleh semakin kecil dibandingkan dengan absorbansi kontrol. Semakin besar konsentrasi dari ekstrak etanol kulit buah rambutan dan vitamin $E$ yang digunakan maka jumlah peroksida yang dihambat juga semakin banyak sehingga absorbansinya semakin kecil. Kemampuan ekstrak etanol kulit buah rambutan dan vitamin $\mathrm{E}$ dalam menghambat pembentukan peroksida bersifat tetap, sedangkan reaksi oksidasi yang terjadi pada asam linoleat mempunyai sifat sebagai reaksi berantai, sehingga semakin lama waktu inkubasi maka jumlah peroksida yang terbentuk akan semakin banyak karena itu nilai absorbansi yang didapatkan akan semakin besar. Hasil ini dapat dilihat pada Tabel 2.

Tabel 2. Hasil absorbansi kontrol ekstrak etanol kulit buah rambutan dan vitamin $\mathrm{E}$

\begin{tabular}{|c|c|c|c|c|c|c|c|c|c|c|c|}
\hline \multirow{3}{*}{ Hari } & \multirow{3}{*}{ Kontrol } & \multicolumn{10}{|c|}{ Absorbansi } \\
\hline & & \multicolumn{2}{|c|}{$10 \mu \mathrm{g} / \mathrm{ml}$} & \multicolumn{2}{|c|}{$20 \mu \mathrm{g} / \mathrm{ml}$} & \multicolumn{2}{|c|}{$40 \mu \mathrm{g} / \mathrm{ml}$} & \multicolumn{2}{|c|}{$80 \mu \mathrm{g} / \mathrm{ml}$} & \multicolumn{2}{|c|}{$160 \mu \mathrm{g} / \mathrm{ml}$} \\
\hline & & a & $\mathrm{b}$ & $a$ & $\mathrm{~b}$ & $a$ & $b$ & $a$ & $b$ & $a$ & $\mathrm{~b}$ \\
\hline 1 & 0,730 & 0,641 & 0,674 & 0,667 & 0,666 & 0,680 & 0,681 & 0,619 & 0,669 & 0,570 & 0,568 \\
\hline 2 & 0,724 & 0,663 & 0,678 & 0,677 & 0,676 & 0,673 & 0,682 & 0,645 & 0,674 & 0,577 & 0,575 \\
\hline 3 & 0,733 & 0,631 & 0,680 & 0,655 & 0,666 & 0,655 & 0,673 & 0,636 & 0,655 & 0,592 & 0,593 \\
\hline 4 & 0,741 & 0,649 & 0,674 & 0,655 & 0,664 & 0,667 & 0,672 & 0,647 & 0,657 & 0,613 & 0,607 \\
\hline 5 & 0,738 & 0,673 & 0,665 & 0,670 & 0,656 & 0,661 & 0,661 & 0,649 & 0,652 & 0,605 & 0,605 \\
\hline 6 & 0,753 & 0,678 & 0,672 & 0,675 & 0,663 & 0,675 & 0,665 & 0,667 & 0,657 & 0,614 & 0,616 \\
\hline 7 & 0,753 & 0,682 & 0,676 & 0,678 & 0,670 & 0,675 & 0,664 & 0,666 & 0,658 & 0,623 & 0,624 \\
\hline
\end{tabular}
Keterangan :

$\mathrm{a}=$ ekstrak etanol kulit buah rambutan

$\mathrm{b}=$ vitamin $\mathrm{E}$

$\mathrm{n}=3 \times$ replikas

Dibaca pada panjang gelombang $499 \mathrm{~nm}$

Gambar 2 berikut menunjukkan hubungan antara ekstrak etanol kulit buah rambutan dan vitamin $\mathrm{E}$ dalam masing- masing konsentrasi $10 \mu \mathrm{g} / \mathrm{ml}, 20 \mu \mathrm{g} / \mathrm{ml}, 40$ $\mu \mathrm{g} / \mathrm{ml}, 80 \mu \mathrm{g} / \mathrm{ml}$, dan $160 \mu \mathrm{g} / \mathrm{ml}$, serta kontrol dengan absorbansinya selama 7 hari. 


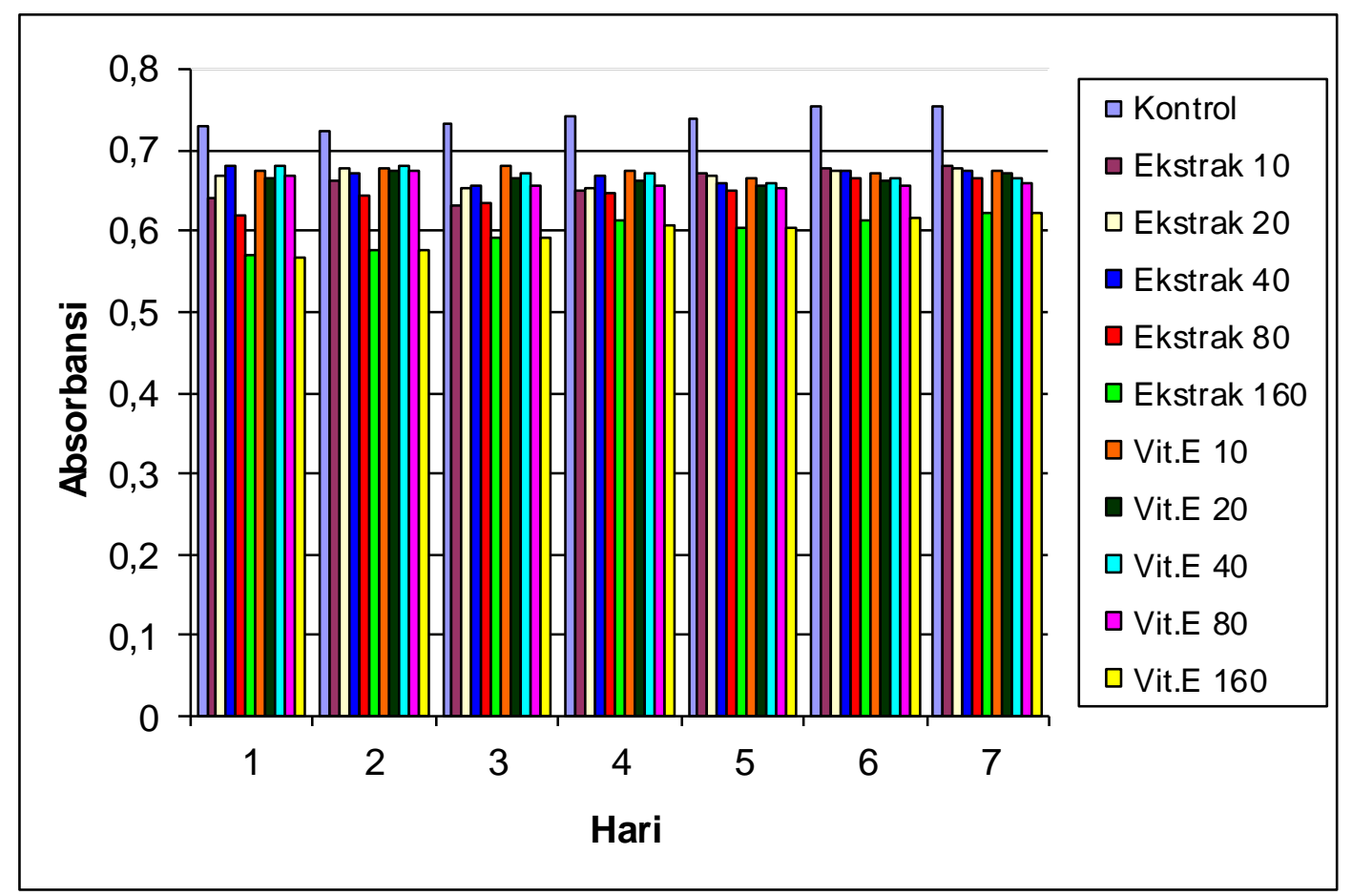

Gambar 2. Diagram hubungan antara ekstrak etanol kulit buah rambutan dan vitamin $E$ dalam masing-masing konsentrasi $10 \mu \mathrm{g} / \mathrm{ml}, 20 \mu \mathrm{g} / \mathrm{ml}, 40 \mu \mathrm{g} / \mathrm{ml}, 80 \mu \mathrm{g} / \mathrm{ml}$, dan $160 \mu \mathrm{g} / \mathrm{ml}$, serta kontrol dengan absorbansinya selama 7 hari

Tabel 3 menunjukkan persentase daya penghambatan radikal bebas asam linoleat dari ekstrak etanol kulit buah rambutan dan vitamin $E$. Nilai tersebut diperoleh dari absorbansi pada Tabel 2. Semakin besar konsentrasi ekstrak etanol kulit buah rambutan dan vitamin $E$ yang digunakan maka jumlah radikal bebas yang dinetralkan oleh ekstrak maupun vitamin $E$ juga semakin banyak, sehingga radikal bebas yang membentuk kompleks ferritiosianat semakin sedikit yang ditandai dengan menurunnya absorbansi. Semakin besar konsentrasi ekstrak etanol kulit buah rambutan dan vitamin $E$ maka daya penghambatan terbentuknya peroksida radikal bebas semakin besar, yang ditandai dengan meningkatnya persen daya penghambatan. Semakin panjang waktu inkubasi maka peroksida radikal bebas yang terbentuk semakin banyak, karena oksidasi asam linoleat yang terus-menerus terjadi. Lain halnya dengan ekstrak etanol kulit buah rambutan dan vitamin $E$, kemampuannya dalam menghambat terbentuknya peroksida radikal bebas bersifat tetap sesuai dengan jumlah gugus hidroksil (-OH) yang dimiliki, sehingga tidak mampu menandingi laju terbentuknya radikal bebas yang terus meningkat, yang ditandai dengan semakin meningkatnya absorbansi. 
Tabel 3. Daya penghambatan radikal bebas asam linoleat oleh ekstrak etanol kulit buah rambutan dan vitamin $\mathrm{E}$

\begin{tabular}{|c|c|c|c|c|c|c|c|c|c|c|}
\hline \multirow{3}{*}{ Hari } & \multicolumn{10}{|c|}{ Daya penghambatan radikal bebas asam linoleat (\%) } \\
\hline & \multicolumn{2}{|c|}{$10 \mu \mathrm{g} / \mathrm{ml}$} & \multicolumn{2}{|c|}{$20 \mu \mathrm{g} / \mathrm{ml}$} & \multicolumn{2}{|c|}{$40 \mu \mathrm{g} / \mathrm{ml}$} & \multicolumn{2}{|c|}{$80 \mu \mathrm{g} / \mathrm{ml}$} & \multicolumn{2}{|c|}{$160 \mu \mathrm{g} / \mathrm{ml}$} \\
\hline & a & b & a & $\mathrm{b}$ & a & $\mathrm{b}$ & a & $\mathrm{b}$ & a & b \\
\hline 1 & 12,17 & 7,56 & 8,61 & 8,75 & 6,83 & 6,69 & 15,16 & 8,36 & 21,90 & 22,25 \\
\hline 2 & 8,32 & 6,33 & 6,46 & 6,58 & 7,04 & 5,79 & 10,79 & 6,82 & 20,30 & 20,48 \\
\hline 3 & 13,91 & 7,13 & 10,63 & 9,10 & 10,54 & 8,12 & 13,19 & 10,54 & 19,12 & 19,11 \\
\hline 4 & 12,38 & 9,10 & 11,67 & 10,43 & 9,95 & 9,32 & 12,69 & 11,34 & 17,22 & 18,03 \\
\hline 5 & 8,80 & 9,88 & 9,25 & 11,08 & 10,51 & 10,48 & 12,08 & 11,60 & 17,99 & 17,99 \\
\hline 6 & 9,96 & 10,74 & 10,38 & 11,97 & 9,97 & 11,70 & 11,49 & 12,81 & 18,41 & 18,14 \\
\hline 7 & 9,42 & 10,24 & 10,01 & 11,00 & 10,35 & 11,81 & 11,52 & 12,58 & 17,25 & 17,18 \\
\hline
\end{tabular}

Keterangan :

$a=$ ekstrak etanol kulit buah rambutan

$\mathrm{b}=$ vitamin $\mathrm{E}$

Rumus: Daya penghambatan $(\%)=\underline{\text { (absorbansi kontrol - absorbansi sampel) }} \times 100 \%$ Absorbansi kontrol

Gambar 3 berikut menunjukkan kemampuan dari ekstrak etanol kulit buah rambutan dan vitamin $\mathrm{E}$ dengan masingmasing konsentrasi $10 \mu \mathrm{g} / \mathrm{ml}, 20 \mu \mathrm{g} / \mathrm{ml}, 40$ $\mu \mathrm{g} / \mathrm{ml}$, $80 \mu \mathrm{g} / \mathrm{ml}$, dan $160 \mu \mathrm{g} / \mathrm{ml}$ dalam menghambat pembentukan radikal bebas asam linoleat selama 7 hari.

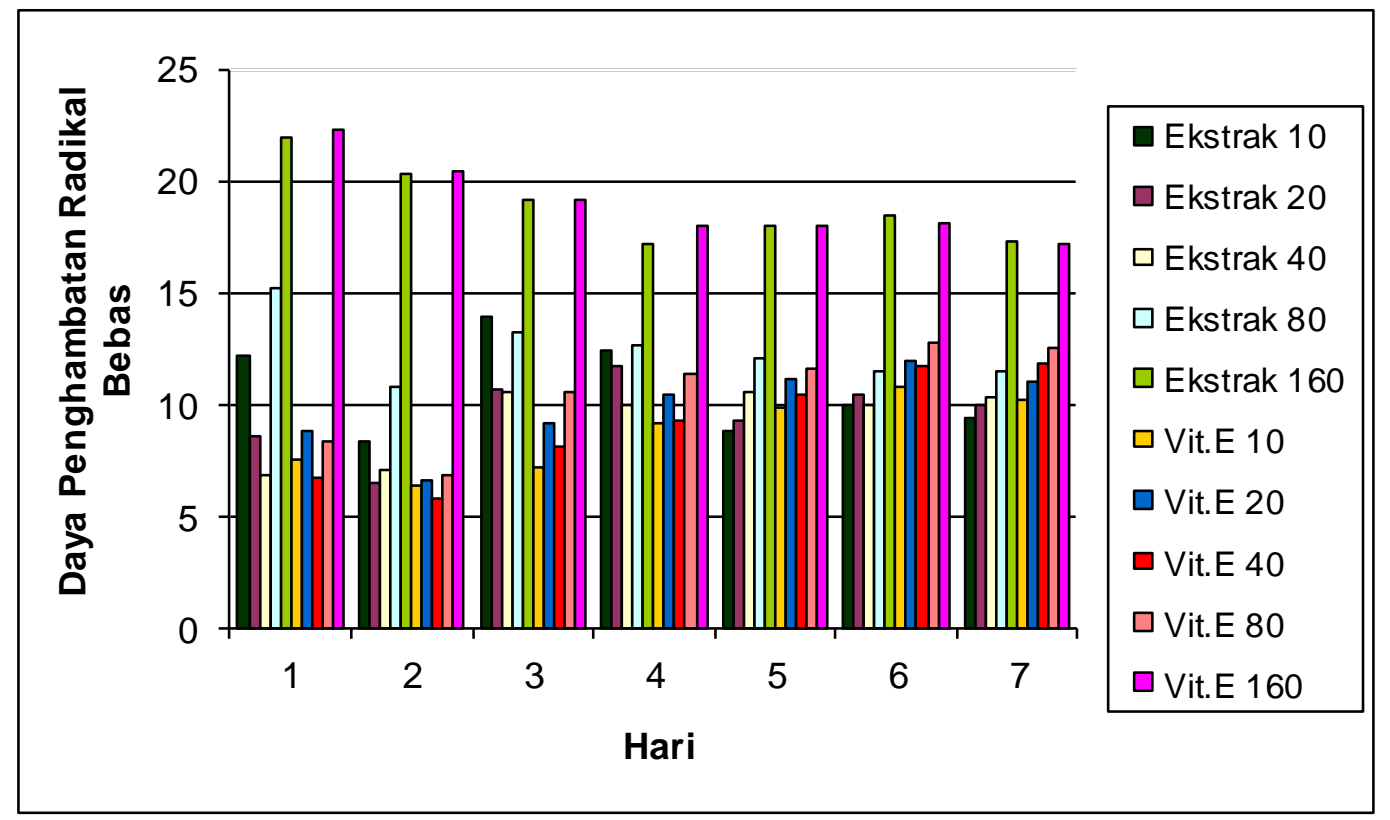

Gambar 3. Diagram daya penghambatan radikal bebas oleh ekstrak etanol kulit buah rambutan dan vitamin E dalam masing-masing konsentrasi $10 \mu \mathrm{g} / \mathrm{ml}, 20 \mu \mathrm{g} / \mathrm{ml}, 40 \mu \mathrm{g} / \mathrm{ml}, 80 \mu \mathrm{g} / \mathrm{ml}$, dan 160 $\mu \mathrm{g} / \mathrm{ml}$ selama 7 hari

Dari data tersebut terlihat adanya korelasi pada peningkatan konsentrasi yang terjadi pada hari ke-5, 6, dan 7. Daya penghambatannya semakin besar seiring 
dengan bertambahnya konsentrasi. Pada hari ke-1 sampai ke-4 daya penghambatannya naik-turun pada penambahan konsentrasi. Hal ini disebabkan karena terjadinya reaksi oksidasi yang tidak terkendali. Sedangkan untuk korelasi penambahan hari hanya terlihat pada konsentrasi $80 \mu \mathrm{g} / \mathrm{ml}$ dan $160 \mu \mathrm{g} / \mathrm{ml}$ yang menunjukkan bahwa semakin lama waktu penyimpanan maka daya penghambatan semakin kecil. Pada konsentrasi $10 \mu \mathrm{g} / \mathrm{ml}$, $20 \mu \mathrm{g} / \mathrm{ml}$, dan $40 \mu \mathrm{g} / \mathrm{ml}$ daya penghambatannya dari hari ke-1 sampai ke7 naik-turun, yang disebabkan karena reaksi yang terjadi tidak sempurna sehingga mempengaruhi terbentuknya kompleks ferritiosianat.

Berdasarkan metode linoleattiosianat ini, yang digunakan sebagai sumber radikal adalah asam linoleat, yang merupakan asam lemak tidak jenuh. Radikal ini bersifat sebagai oksidator, yang akan mengoksidasi ion ferro (dari ferro klorida) menjadi ion ferri yang dengan adanya ion tiosianat akan menghasilkan kompleks ferritiosianat yang berwarna merah dan dapat diukur intensitasnya pada panjang gelombang $499 \mathrm{~nm}$. Reaksi yang terjadi adalah sebagai berikut :

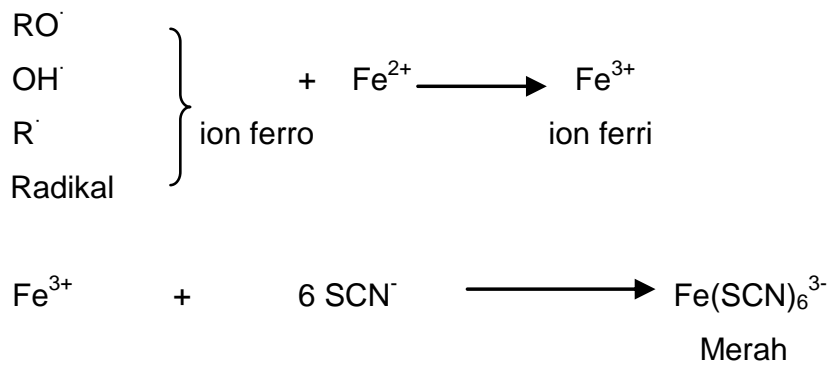

Penghambatan terbentuknya radikal bebas asam linoleat oleh ekstrak etanol kulit buah rambutan dianalisis dengan metode parametrik General Linear Model (GLM), diperoleh nilai signifikansi $0,00(p<0,05)$ pada variabel hari, yang berarti penghambatan oleh ekstrak dari hari kesatu sampai ketujuh berbeda bermakna. Hal ini menunjukkan bahwa terdapat kemampuan yang berbeda dari ekstrak etanol kulit buah rambutan dalam menghambat pembentukan radikal bebas asam linoleat pada hari kesatu sampai ketujuh. Pada variabel konsentrasi juga diperoleh nilai signifikansi 0,00 ( $p<$ 0,05 ) yang berarti penghambatan oleh ekstrak antar konsentrasi berbeda bermakna. Perbedaan konsentrasi dari ekstrak etanol kulit buah rambutan mempunyai kemampuan menghambat pembentukan radikal bebas asam linoleat yang berbeda. Sedangkan pada variabel interaksi antara hari dan konsentrasi diperoleh nilai signifikansi $0,072(p>0,05)$ yang berarti penghambatan oleh ekstrak tidak berbeda bermakna. Dimana antar konsentrasi dari ekstrak etanol kulit buah rambutan pada hari yang sama, mempunyai kemampuan menghambat pembentukan radikal bebas asam linoleat yang sama. Hasil GLM untuk vitamin $\mathrm{E}$ menunjukkan hasil yang tidak berbeda bermakna pada variabel hari, tetapi berbeda bermakna pada variabel konsentrasi dan variabel interaksi antara hari dan konsentrasi. Hal tersebut menunjukkan 
bahwa vitamin $\mathrm{E}$ pada hari kesatu sampai ketujuh mempunyai kemampuan yang sama dalam menghambat pembentukan radikal bebas asam linoleat. Sedangkan antar konsentrasi dari vitamin $\mathrm{E}$ mempunyai kemampuan menghambat pembentukan radikal bebas asam linoleat yang berbeda dan antar konsentrasi dari vitamin E pada hari yang sama, mempunyai kemampuan menghambat pembentukan radikal bebas asam linoleat yang berbeda.

Pada Post Hoc Test Homogeneous Subset untuk penghambatan ekstrak etanol kulit buah rambutan pada variabel hari terdapat empat subset yang artinya perbedaan waktu menyebabkan perbedaan yang signifikan satu dengan yang lainnya. Pada variabel konsentrasi terdapat tiga subset yang artinya perbedaan konsentrasi menyebabkan perbedaan yang signifikan satu dengan yang lain. Sedangkan hasil Post Hoc Test Homogeneous Subset untuk penghambatan vitamin $E$ pada variabel konsentrasi terdapat empat subset yang artinya perbedaan konsentrasi menyebabkan perbedaan yang signifikan satu dengan yang lain. Pada variabel interaksi antara hari dan konsentrasi terdapat tujuh subset yang artinya interaksi antara hari dan konsentrasi yang berbeda menyebabkan perbedaan yang signifikan.

Tabel 4. Hasil Post Hoc Test Homogeneous Subset ekstrak etanol kulit buah rambutan

\begin{tabular}{cccccc}
\hline $\begin{array}{c}\text { Konsentrasi } \\
(\mu \mathrm{g} / \mathrm{ml})\end{array}$ & $\mathbf{1 0}$ & $\mathbf{2 0}$ & $\mathbf{4 0}$ & $\mathbf{8 0}$ & $\mathbf{1 6 0}$ \\
\hline $\mathbf{1 0}$ & - & TB & TB & $\mathrm{B}$ & $\mathrm{B}$ \\
$\mathbf{2 0}$ & TB & - & TB & $\mathrm{B}$ & $\mathrm{B}$ \\
$\mathbf{4 0}$ & TB & TB & - & B & B \\
$\mathbf{8 0}$ & B & B & B & - & B \\
160 & B & B & B & B & - \\
\hline Keterangan: & & & & &
\end{tabular}

TB $=$ tidak berbeda bermakna

$\mathrm{B}=$ berbeda bermakna

Tabel 5. Hasil Post Hoc Test Homogeneous Subset vitamin E

\begin{tabular}{cccccc}
\hline $\begin{array}{c}\text { Konsentrasi } \\
(\mu \mathrm{g} / \mathrm{ml})\end{array}$ & $\mathbf{1 0}$ & $\mathbf{2 0}$ & $\mathbf{4 0}$ & $\mathbf{8 0}$ & $\mathbf{1 6 0}$ \\
\hline $\mathbf{1 0}$ & - & $\mathrm{B}$ & $\mathrm{TB}$ & $\mathrm{B}$ & $\mathrm{B}$ \\
$\mathbf{2 0}$ & $\mathrm{B}$ & - & TB & TB & B \\
$\mathbf{4 0}$ & $\mathrm{TB}$ & TB & - & $\mathrm{B}$ & $\mathrm{B}$ \\
$\mathbf{8 0}$ & $\mathrm{B}$ & $\mathrm{TB}$ & $\mathrm{B}$ & - & $\mathrm{B}$ \\
$\mathbf{1 6 0}$ & $\mathrm{B}$ & $\mathrm{B}$ & $\mathrm{B}$ & $\mathrm{B}$ & - \\
\hline Keterangan : & & & & &
\end{tabular}

TB = tidak berbeda bermakna

$\mathrm{B}=$ berbeda bermakna

Dari Tabel 4 diketahui bahwa pada konsentrasi yang berbeda dari ekstrak etanol kulit buah rambutan mempunyai kemampuan yang berbeda dalam menghambat pembentukan radikal bebas asam linoleat. Tabel 5 menunjukkan bahwa vitamin E pada konsentrasi yang berbeda mempunyai kemampuan menghambat pembentukan radikal bebas asam linoleat yang berbeda.

Untuk melihat perbedaan aktivitas antioksidan antara ekstrak etanol kulit buah rambutan dengan vitamin $\mathrm{E}$ maka dilakukan 
analisis statistik dengan menggunakan Independent Sample T-Test, dan diperoleh nilai signifikansi $0,112(p>0,05)$ yang berarti antara ekstrak etanol kulit buah rambutan dengan vitamin $\mathrm{E}$ tidak berbeda bermakna.

Ekstrak etanol kulit buah rambutan mempunyai aktivitas antioksidan yang ditandai dengan menurunnya nilai absorbansi ekstrak etanol kulit buah rambutan dibandingkan dengan kontrol. Ekstrak etanol kulit buah rambutan mempunyai kemampuan yang sama dengan vitamin E pada setiap konsentrasinya dalam menghambat pembentukan radikal bebas asam linoleat.

\section{KESIMPULAN}

Ekstrak etanol kulit buah rambutan (Nephelium lappaceum, L.) mempunyai aktivitas sebagai antioksidan dengan mekanisme menghambat pembentukan radikal bebas asam linoleat. Kemampuan menghambat pembentukan radikal bebas asam linoleat dari ekstrak etanol kulit buah rambutan sama dengan vitamin $\mathrm{E}$ pada setiap konsentrasinya.

\section{DAFTAR PUSTAKA}

Almatseir, S, 2001, Prinsip Dasar IImu Gizi, Gramedia Pustaka Utama, Jakarta, 175

Anshory, H., Suparmi, dan Tamimy, A., S., 2006, Aktivitas antioksidan ekstrak etanol kulit buah rambutan (Nephelium lappaceum, L.) terhadap penangkapan radikal bebas DPPH, Jurnal IImiah Farmasi Universitas Islam Indonesia, Vol. 3, No. 1, pp. 9-15

Backer, C.A. and Bakhuizen van de Brink, R.C., 1965, Flora of Java: Book II, N.V.P. Noor Dhoff-Groningen The Netherland
Halliwell, B. and Gutteridge, J.M.C., 2000, Free Radical in Biology and Medicine, Oxford University Press, New York

Pokorni, J., Yanishlieva, N., and Gordon, M., 2001, Antioxidant in Food; Practical Applications, CRC Press, New York

Robinson, T., 1995, Kandungan Organik Tumbuhan Tingkat Tinggi, Penerbit ITB Bandung, 191-196, 209

Rohman, A., dan Riyanto, S., 2005, Daya antioksidan ekstrak etanol daun kemuning (Murraya paniculata (L) Jack) secara in-vitro, Majalah Farmasi Indonesia, 16 (3), pp. 136140

Sibuea, P., 2003, Antioksidan Senyawa Ajaib Penangkal Penuaan Dini, Sinar Harapan, Jogjakarta

Sofia, Dinna, 2003, Antioksidan dan Radikal Bebas, available at http://chem-istry.org (diakses 13 November 2007)

Takaya Y., Kondo Y., Furukawa T. and Niwa, M. 2003. Antioxidant constituent of radish sprout (kiware-daikon), Raphanus sativus L. J Agric. Food Chem. 51(27): 8061-8066

Yildirim, A., Oktay, M., and Bilaloglu, V., 2001, The Antioxidant Activity of the Leaves of Cydonia vulgaris, Turk J. Med Sci, 31: 23-27 